\title{
Biskop Daugaard og Rødding Højskole
}

\section{Af F. Elle Jensen}

Som bekendt mødte Højskolerne i deres første Tid kun ringe Forstaaelse hos Myndighederne og $i$ det hele taget $i$ de akademiske Kredse, hvor man som Regel, naar det kom højst, indskrænkede sig til at betragte dem med en vis venlig Nedladenhed. De Ord, hvormed Kultusministeren, Professor Madvig, i Rigsdagen afviste Tanken om Højskolen i Sorø, at han ikke kunde støtte »en Karakteren af Danskhed monopoliserende Anstalt« - en herlig sproglig Mundfuld - giver vistnok et godt Udtryk for Overklassens Syn paa Grundtvigs Skoletanker.

Saa meget mere bemærkelsesværdigt er det derfor at se, hvor roligt og anerkendende en ellers saa konservativ Mand som Biskop Daugaard i Ribe,") der meget vilde have sig frabedt at blive kaldt Grundtvigianer, dømmer om Rødding Højskole. Hans Udtalelser, der fremkom som Svar paa en Forespørgsel fra Kultusministeriet, og som nedenfor skal meddeles, har saa vidt mig bekendt ikke tjdligere været offentliggjort; de gengives her efter Bispearkivets Kopibog (Landsarkivet i Viborg).

Den 7. Januar 1854 tilskrev Ministeriet for Kirke- og Undervisningsvæsenet Biskoppen følgende:

"Til Højskolen i Rødding er der i hvert af de 2de foregaaende Finantsaar bevilget en Understøttelse af $300 \mathrm{Rbd}$. af det $i$ Finantsloven opførte Tilskud til højere Bondeskoler.

Bestyrelsen for bemeldte Skole har nu i hoslagte Andragende om ligeledes for indeværende Finantsaar at forundes en Understøttelse for Skolen.

Forinden videre i Anledning heraf foretages, skulde man imidlertid tjenstligst udbede sig D. H.s (Deres Højærvær-

*) Født 1796, Biskop over Ribe Stift fra 1850 til sin D $\varnothing d^{\prime}$ i 1867. 
digheds) Yttringer om Sagen med det Indesluttede tilbagesendt behageligst meddelte."

Herpaa svarede Biskoppen d. 17. Januar:

»Ved hermed at tilbagesende det mig under 7. d. M. af det høie Ministerium til Betænkning tilstillede Andragende fra $\mathrm{Be}-$ styrèlsen for Rødding Høiskole om et Tilskud af Finantserne til Beløb 300 Rbd., skal jeg ikke undlade hermed ærbødigst at meddele, at det er kun saare Lidet, hvad jeg veed om denne Skoles Virksomhed, oconomiske Forfatning m. v., da jeg ikke paa Embeds Vegne staar i noget Forhold til denne Skole som saadan; Bestyrelsen og Lærerne har jeg ei heller havt noget Bekjendtskab til; ligesaalidet har jeg staaet i Forbindelse med nogen af Skolens Elever. Mit Kundskab over dette Institut strækker sig derfor kun til det, som jeg har erfaret om samme af den i Aaret 1853 trykte Beretning og hvad jeg leilighedsviis og tilfældigviis har kunnet høre derom i daglig Tale. Men saavidt jeg kan skjønne, er det overeensstemmende med Sandheden, at denne Stiftelse i sin første Virksomhedsperiode før Oprørskrigens Udbrud stiftede megen Gavn og vakte hos mange Slesvigere en klar og fast Bevidsthed om deres Stilling og Pligt som Danske og som Undersaatter af Danmarks Konge. Efter at den paa ny ved Krigens Ende er traadt i Virksomhed, har det især været dens Formaal at bibringe unge Mennesker af Bondestanden, hvis Barndomsunderviisning i Almueskolen er tilendebragt, saa og andre Ynglinge, der ei er bestemte for Studeringer, saadanne Kundskaber, som deels befordre deres aandelige Uddannelse i Almindelighed, deels dueliggøre dem til deres fremtidige Stilling i Livet, og saavidt jeg har erfaret, skal den ret heldigen have løst sin Opgave. Hvad der har forekommet mig mindre heldigt i Skolens Undervisningsplan, er at denne synes mig at være for høit anlagt for unge Mennesker, der kun ere i Besiddelse af de Forkundskaber, som Almueskolen i Almindelighed giver, og at Examination af det Foredragne anvendes mindre, end det ifølge Disciplenes Dannelsestrin synes nødvendigt, ligesom der $\mathrm{i}$ det Hele indrømmes Disciplene større Frihed med Hensyn til Underviisningen, end det efter min Er- 
faring synes ønskeligt. Men desuagtet stifter Skolen efter den herskende Mening ikke liden Nytte, og det var beklageligt, om den af Mangel paa Subsistensmidler skulde gaae tilgrunde, hvilken Skjæbne synes at true den, dersom den nægtes den Hjælp, som i et Par Aar har været den og det af det Offentlige.» 